\title{
Perception of Stakeholders on the Compliance of Sports Facilities to Relevant Standards in Selected Universities in South West Nigeria
}

\author{
Godwin Ehis Oseghale, \\ Ime Johnson Ikpo, \\ Department of Building, \\ Obafemi Awolowo University, Ile- Ife, Nigeria.
}

Doi: 10.19044/esj.2018.v14n18p264 URL:http://dx.doi.org/10.19044/esj.2018.v14n18p264

\begin{abstract}
This paper examines the level of compliance of sports facilities, in selected universities in South-Western Nigeria to relevant standards (National and International standards). Data were collected using a structured questionnaire which was administered on sports men and women (4 male, 2 female). Personnel responsible for maintenance of sports facilities in the universities were also sampled (two groundsmen from each University, the Director of Sports and two other members of the sport Council, Director of Works, four maintenance Supervisors, and two maintenance administrative staff, and eighteen maintenance operatives in each of the selected University). The study incorporated all the fifteen sports featured at the Nigeria University Games Association (NUGA) competitions. Three federal universities were purposively selected because these have facilities for all the fifteen sports and have hosted national and international sporting events. A total of four hundred and fifty four copies of the questionnaires (454) were administered and (342) copies were retrieved and found useful for analysis. Two hundred and sixty one copies $(71.7 \%)$ copies of questionnaire were retrieved from sports men and women and 81 copies (90\%) from maintenance staff in the universities sampled. Data obtained were analysed using frequency distribution, percentages and mean response analysis. The findings revealed that football field; hockey and cricket pitches were rated very low on the availability of sprinklers. The hard courts were rated very low on 'crack free' and 'free of holes. The swimming pool was equally rated very poorly on pool chemical balance and cleanliness of water. The study concluded that sports facilities in South West Nigeria were not complying with the requisite national and international standards. The study therefore recommended immediate response from the management of the sports facilities in order to return the
\end{abstract}


facilities to normal operations halt accelerated deterioration, correct cited safety hazards and life safety code violations.

Keywords: Sports, Facilities, Maintenance, Compliance, Standards

\section{Introduction}

In recent times the developments of sports facilities has been given prominence in Nigerian university campuses, primarily because excellence depends much on intellectual capability. It is in these university sport complexes that future leaders, captains of industry, entrepreneurs, professionals and scientists develop and sustain their physical component as well as stimulate their intellectual threshold (Mat, et. al., 2009). A sport facility is a place where sports and ancillary affairs take place. In order to optimise the use of these facilities, their availability and functionality are essential at all times. Sports have been considered as the most crucial tool for managing a society and preventing adverse medical conditions such as obesity and other chronic disorders. For this reason, the availability of sports facilities through sustainable maintenance management strategies is of prime importance to provide for the needs and expectations of different classes of people including the physical training department, sports men and women, spectators, and the university community as a whole (Adeniran and Ikpo, 2001; Oseghale, 2016).

Sports facilities constitute one of the essential determinants of sports management (Kabido, 1996). According to Ikhioya (1999) availability of standard sports facilities, and standard sports arena for competition is paramount towards promotion and development of sports. Emiola (1999) noted that training and competing with modern and standard sports facilities are part of the motivation for athlete's participation in sports. Therefore, if developing countries such as Nigeria wishes to raise the standard of their games, improved their performance, and achieve success at international sporting events there is need for all concerns in the field of sports to develop and maintain sports facilities in the universities as it is the place where there is a pool of young and talented people of sports men and women (Oseghale, 2016). It is equally important that sports facilities satisfy the requirements of relevant governing bodies (Bartlett, James, Ford, and Temple, 2008).

For any successful execution of sports programme, there must be availability of qualitative and of quantitative facilities to the required standards (Adi, 2005). Ladani (1990) observed that sports facilities can be said to represent the tools that the coaches and the participants must have or use to facilitate the coaching of sports and for competitions. Akpe (1995) observed that if sports programme are to achieve any success and for effective management, there must be availability of sports facilities meeting with the 
relevant standards of the governing bodies (Diejomaoh, 2015; Oseghale, 2016). The provision and maintenance of sport facilities by the college or university will enhance and promote healthy sports competitions. Amusa (2000) observed that lack of sports facilities hinders the organization and management of sports programmes in tertiary institutions. According to Talabi (1998), the attainment of a world class status in sports is a reflection of the presence of top standard equipment and facilities.

Ekpe (2001) noted that it is difficult to separate the standard of sports in a country from the standard of facilities and equipment available. Omoruan (1996) noted that facilities and equipment are the greatest among all factors that affect the growth of a sport. Ogbemudia (2001) emphasized that if Nigeria must attain the desired standards in performance and attain top ratings in the Olympic Games, then the planning and management of sports facilities and equipment must not only be broad based but also be backed-up with adequate provision and maintenance of the available facilities and equipment to relevant standard.

The nature of sports events and competition requires that sport facilities meet the minimum standards of national and international governing bodies in order to host competitions. Some examples of National governing bodies in sports in Nigeria include Badminton Federation of Nigeria, Nigeria Basketball Association, and Nigeria Football Federation, Gymnastics Federation of Nigeria, Nigeria Hockey Federation, Nigeria Olympic committee and a host of others. Some examples of international governing bodies in sports include UK Sports, Central Council for Physical Recreation (CCPR), and International Olympic Committee (IOC) among others. To this end, sports facilities require regular maintenance at all times. The testing of the performance of a sport surface is carried out to determine its level of compliance with minimum standard set by the national and international governing bodies before any major competition (Bartlett, 2008; Oseghale, 2016). This paper therefore examines the perception of stakeholders on the level of compliance of sport facilities to national and international standards in selected universities in south western Nigeria.

\section{Research Methodology}

The study population comprises sportsmen and women and staff of maintenance department in selected universities in south west Nigeria. The sample frame covered all the universities in South west, Nigeria accredited by the National Universities Commission (NUC). The sample frame also covers all fifteen sporting events that features in Nigerian University Games Association (NUGA). (Nigerian university games association (NUGA), organise level sports events in Nigeria. It hosts interuniversity sports competition called the University Games). A total of fifteen games feature in 
NUGA. The games are: badminton, basketball, chess, cricket, football, handball, hockey, judo, squash racket, swimming, table tennis, taekwondo, tennis, track and field and volleyball. A pilot survey conducted for this study revealed that only three federal universities have all the 15 different sports for the study and have hosted National and international sporting events. The three universities are: Obafemi Awolowo University, Ile-Ife; University of Ibadan and University of Lagos. These three universities were therefore selected for the study. For each of the fifteen games two coaches were selected (one for the male and one foe female teams), All four members of NUGA technical committee in South west, two groundsmen from each University, the Director of Sports and two other members of the sport Council, Director of Works, four maintenance Supervisors, and two maintenance administrative staff, and eighteen maintenance operatives in each of the selected University, and six sports men and women ( 4 male, 2 female) in each of the fifteen games in the selected Universities. Therefore the total sample size is four hundred and fifty four respondents. A total of four hundred and fifty four copies of the questionnaires (454) were administered and (342) copies were retrieved and found useful for analysis. Two hundred and sixty one copies $(71.7 \%)$ out of the total three hundred and four- two duly completed copies of questionnaire were retrieved from sports men and women in the universities sampled. This was lower than the $90 \%$ responses obtained from the staff of maintenance department, in which 81 copies of questionnaire were returned out of the 90 copies administered.

\section{Results and Discussion \\ General information about the respondents}

The distribution of the respondents showed that staff involved in the sports units in the study represented $16.5 \%$ of the respondents, while $83.5 \%$ were students and $2.7 \%$ of the respondents have been chairman and directors of sports council at one time in the universities. Also $9.2 \%$ were coaches, while $24.9 \%$ were captains and $60.5 \%$ were members of the universities sport teams and $77 \%$ of the respondents were male and $23 \%$ female. The distribution of the respondents showed that $45.2 \%$ spent $1-5$ hours, participating in sports recreationally/per week, $23.4 \%$ spent $6-10$ hours/week, $18.4 \%$ spent $11-15$ hours/week while $8.8 \%$ spent $16-20$ hours/week and $4.2 \%$ spent $21-25$ hours/week. This shows that the respondents have adequate knowledge and experience in the field of sports to supply adequate information.

\section{Level of Compliance of Sports Facilities to National and International Standards}

The respondents were asked to rate the sports facilities for the fifteen NUGA sporting events in their universities according to the level of 
compliance to national and international standards. The respondents were asked to indicate their perception on a 5 point scale ranging from 1unacceptable, 2- very poor, 3 - satisfactory, 4 - very good and 5 - excellent. This is presented in Table 1.

Table 1: Level of Compliance of Sports Facilities to National and International Standards as Perceived by Sportsmen and Women

\begin{tabular}{llll}
\hline Sport Facilities & Mean & SD & Rank \\
\hline Track and field & 3.7240 & 1.0139 & 1 \\
Swimming pool & 3.4686 & 1.1587 & 2 \\
Football pitch & 3.4502 & 1.1351 & 3 \\
Table tennis & 3.4409 & .9937 & 4 \\
Squash & 3.4219 & .9201 & 5 \\
Volleyball court & 3.3834 & .9632 & 6 \\
Basketball court & 3.3175 & .9073 & 7 \\
Tennis court & 3.3028 & .9612 & 8 \\
Judo hall & 3.2350 & .8846 & 9 \\
Handball & 3.1967 & .8994 & 10 \\
Taekwondo playground & 3.1634 & .9661 & 11 \\
Badminton court & 3.1359 & .8840 & 12 \\
Cricket pitch & 3.0735 & .9040 & 13 \\
Badminton court & 3.0701 & .9928 & 14 \\
Hockey pitch & 3.0044 & 2.2301 & 15 \\
\hline
\end{tabular}

Mean response analysis was calculated for the rating of the sports facilities on their level of compliance to national and international standards. The finding reveals that Track and field with a mean score of (3.72) was rated numbers 1 , followed by swimming pool with a mean score of (3.47), football pitch with a mean score of (3.45), table tennis gym mean score of (3.44), squash court with a mean score of (3.42), However, hockey pitch had the least rating with a mean score of 3.004 .

\section{Assessment of Sports Facilities Level of Compliance to National and International Standards using Performance Indicators and Parameters}

The level of compliance of the sports facilities to national and international standards were further assessed using the performance indicators and parameters for rating the standards of courts and fields of play as in Lee, (2008). The respondents were asked to use these parameters to assess the football pitch, cricket/ hockey pitch and the outdoor hard courts areas, the swimming pool, and the quality of lighting in the sports complexes. The respondents were asked to indicate their perception on a five point scale ranging from 1 - unacceptable, 2 - very poor, 3 - satisfactory, 4 - very good and 5 - excellent. This is presented in Table 2. 
Table 2: Level of Compliance of Sport Facilities to National and International Standard using the Assessment Parameters as Perceived by Sportsmen and Women

\begin{tabular}{|c|c|c|c|c|}
\hline Parameters & Mean & SD & Rank & $\begin{array}{l}\text { Overall } \\
\text { rank }\end{array}$ \\
\hline \multicolumn{5}{|l|}{ Football pitch } \\
\hline Ease of running on the pitch & 3.4016 & .9720 & 1 & \\
\hline Ball bounce/roll performance & 3.3984 & .9275 & 2 & \\
\hline Type of grass & 3.3765 & 1.0571 & 3 & \\
\hline Type of vegetation & 3.3478 & .9288 & 4 & \\
\hline Friction/adhesion of the pitch & 3.3440 & .9280 & 5 & \\
\hline Ease of turning/pivoting on the pitch & 3.3320 & .9346 & 6 & \\
\hline Pitch gradient & 3.3294 & .9398 & 7 & \\
\hline Availability of sprinkler & 3.0886 & 1.2537 & 8 & \\
\hline Mean Average & 3.3273 & & & 3 \\
\hline \multicolumn{5}{|l|}{ Cricket pitch } \\
\hline Type of grass & 2.9370 & 1.1872 & 1 & \\
\hline Ease of turning/pivoting on the pitch & 2.9034 & 1.0923 & 2 & \\
\hline Pitch gradient & 2.8833 & 1.1143 & 3 & \\
\hline Ease of running on the pitch & 2.8675 & 1.1019 & 4 & \\
\hline Friction/adhesion of the pitch & 2.8417 & 1.0939 & 5 & \\
\hline Ball bounce/roll performance & 2.8285 & 1.0807 & 6 & \\
\hline Availability of sprinklers & 2.8067 & 1.1684 & 7 & \\
\hline Type of vegetation & 2.7899 & 1.1464 & 8 & \\
\hline Mean average & 2.8332 & & & 5 \\
\hline \multicolumn{5}{|c|}{ Hard courts (Basketball, Handball, Tennis and Volleyball courts) } \\
\hline Straightness of marking line & 3.5301 & .9631 & 1 & \\
\hline Ball bounce/roll performance & 3.4739 & .9420 & 2 & \\
\hline Coefficient of friction (slip, slide, nonslip) & 3.2323 & .9927 & 3 & \\
\hline Colour & 3.1938 & 1.0103 & 4 & \\
\hline Free of dry rot/mold & 3.1804 & 1.0643 & 5 & \\
\hline Smoothness of the court & 3.1589 & .9951 & 6 & \\
\hline Free of holes & 3.0909 & .9778 & 7 & \\
\hline Crack free & 3.0158 & 1.1054 & 8 & \\
\hline Mean average & 3.2345 & & & 4 \\
\hline \multicolumn{5}{|l|}{ Swimming pool } \\
\hline Size of pool & 3.5740 & 1.1712 & 1 & \\
\hline Pool temperature & 3.4133 & 1.0057 & 2 & \\
\hline Water leakage & 3.3991 & 1.0343 & 3 & \\
\hline Clogging of water outlet & 3.3864 & 1.0516 & 4 & \\
\hline Water pressure & 3.3750 & 1.0599 & 5 & \\
\hline Cleanliness of water & 3.3644 & 1.0651 & 6 & \\
\hline Pool chemical balance & 3.2768 & 1.1102 & 7 & \\
\hline Mean average & 3.3984 & & & 1 \\
\hline Quality of lighting in sport complex & 3.3319 & 1.1472 & 1 & 2 \\
\hline
\end{tabular}

Mean response analysis was calculated for the parameters for assessing the football pitch. The result showed that the football pitch was rated number 
one on the ease of running on the pitch with a mean score of 3.402 followed by ball bounce and rolls performance with a mean score of 3.398, type of grass with a mean score of 3.377, type of vegetation with a mean score of 3.348 and friction/adhesion of the pitch with a mean score of 3.344. However, the football pitch was rated, lowest on availability of sprinklers with a mean score of 3.089 and pitch gradient with a mean score of 3.329.

Cricket/Hockey pitch was rated number one on type of grass with a mean score of 2.937 followed by 2 - ease of turning/pivoting on the pitch with a mean score of (2.903), 3 - pitch gradient with a mean score of (2.833), 4 ease of running on the pitch with a mean score of (2.868) and friction/ adhesions of the pitch with a mean score of (2.842). Also the cricket/hockey pitch was rated lowest on type of vegetation and availability of sprinkles.

The mean response analysis result for the hard courts (basketball, handball, tennis and volleyball courts) shows that the courts were rated number one on straightness of marking lines with a mean score of 3.530. This was followed by ball bounce/roll performance with a mean score of (3.474), coefficient of frictions (slip, slide vs. nonslip) with a mean score of (3.232), colours of painting with a mean score of (3.194) and free of dry rot/mold with a mean score of (3.180). However the courts were rated very low on crack free, free of holes and smoothness of the courts.

Mean response analysis result for the swimming pool showed that the pools were rated number one on the size of the swimming pool with a mean score of (3.579). This was followed by pool temperature with a mean score of (3.413), water leakage with a mean score of (3.399), clogging of water outlets with a mean score of (3.386) and water pressure with a mean score of (3.375). However the swimming pools were rated lowest on pool chemical balance and followed by cleanliness of water.

\section{Conclusion and Recommendation}

This study assessed sports facilities level of compliance to relevant standards in selected universities in Southwest Nigeria. The three universities sampled have facilities for the fifteen NUGA games. The mean rank of respondents on the level of compliance of the sports facilities to national and international standards were low and as such were not satisfactory. The athletes rated the level of compliance of the sports facilities to national and international standard low. In the three universities sampled the football field, hockey and cricket pitches were rated very low on the availability of sprinklers. The hard courts were rated very low on 'crack free' and 'free of holes'. This also poses serious danger to the athletes as it increases the risk of injury. The swimming pool was equally rated very poorly on pool chemical balance and cleanliness of water. The study therefore recommends urgent attention from the school authorities and management of the sports council to 
the sports facilities. Immediate response from the university authority and members of the university sports council will return the facilities to normal operations halt accelerated deterioration.

\section{References:}

1. Adeniran, S. O. and Ikpo, I. J. (2001). Management Strategies for University Sports Facilities. African Journal for Physical, Health Education, Recreation and Dance, 7(2), 349-360.

2. Adi, D. (2015). Sports management practices in tertiary institution in Taraba state, Nigeria. M.Sc. thesis in department of Health and Physical education, university of Nigeria, Nsukka. University of Ngeria virtual library.

3. Akpe, F. A. (1995). Determinants of sports achievement in Edo State between 1980 and 1985. Proceedings of guinness NUGA 86 Sports clinic, Ibadan.

4. Bartlett, M. D., James I, T., Ford, M; Temple, M. J., (2008). Testing Natural Turf Sports Surfaces; The Value of Performance Quality Standards. Journal of sports Engineering and Technology, 223(16), 21-29.

5. Diejomaoh, S. O. E. Akarah, E., Tayire, F.O., (2015). Availability of facilities and equipment for sports administration at the local government areas of Delta State, Nigeria. Academic Journal of interdisciplinary studies. 4(2), 307-312.

6. Ekpe, S. (2001). Problems of Sports Development in Nigeria (Report of National Committee on Problem of Sports Development in Nigeria). 583-602.

7. Emiola T. D. (1999) Patterns of school fund management in Nigeria. Journal of management, 2(1), 5-9.

8. Ikhioya, O. S. A. (1999) Relationship between mediators of job satisfaction and commitment of physical education teachers in Bendel State secondary schools. Unpublished Ph.D. thesis report, University of Ibadan, Ibadan.

9. Ladani, B. A. (1990) The civic-child and sports in Nigeria. Abuja, still water publication,

10. Lee, H. H. Y. (2008): Building Maintenance in the Sport and Leisure Facilities. Unpublished Ph.D thesis, University of South Australia, Australia.

11. Mat, S., Sopian, K., Moktar, M., Hashim, S. H., Abdu Rashid, A., Zian, M. F. M., and Abdullah, G.N. (2009): Managing sustainable campus in Malaysia-Organizational approach and measures, European journal of social science. 8(2), 201-214. 
12. Ogbemudia, S.O. (2001). Problems of Sports Development in Nigeria (Report of National Committee on Problem of Sports Development in Nigeria 3) 474 - 498.

13. Omoruan, J. C. (1996). A handbook on physical education sports and recreation. Zaria: Asekome \& co.

14. Oseghale, G. E. (2016). Maintenance Management Strategies for Sports Facilities in selected University in Southwestern Nigeria. Unpublished Ph.D thesis, Department of Building, Obafemi Awolowo University, Ile-Ife.

15. Talabi, A.E. (1998). Poor Facilities: A Deterrent to Skill Excellence in Sports. Journal of Nigeria Academy of Sports Administration. 5 (1), 9396 